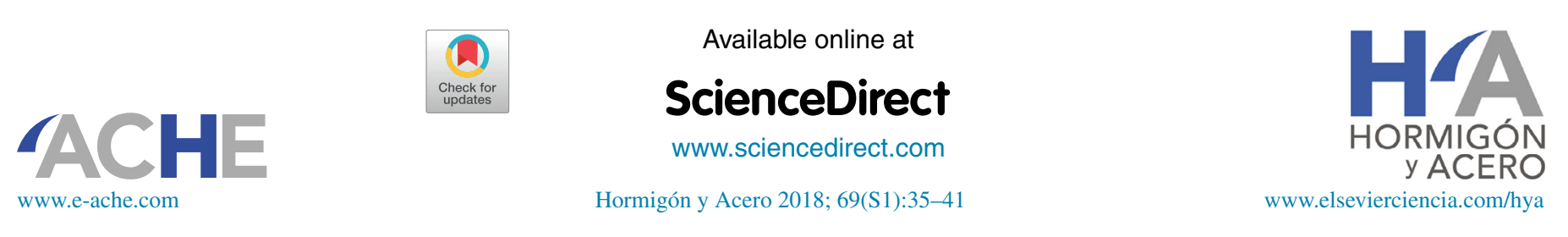

\title{
Progreso's viaduct in Yucatan, Mexico: First durable concrete structure in the world made with stainless steel
}

\section{El viaducto de Progreso en Yucatán, México: primera estructura de concreto durable en el mundo construida con acero inoxidable}

\author{
Andrés A. Torres-Acosta ${ }^{\mathrm{a}, *}$, Miguel Martínez-Madrid ${ }^{\mathrm{b}}$, Pedro Castro-Borges $^{\mathrm{c}}$ \\ a Instituto Mexicano del Transporte, Coordinación de Ingeniería Vehicular e Integridad Estructural, Investigador Titular, SNI II Km 12 Carretera \\ Querétaro-Galindo, Mpio. Pedro Escobedo, Sanfandila, Querétaro, Mexico \\ ${ }^{\mathrm{b}}$ Instituto Mexicano del Transporte, Coordinación de Ingeniería Vehicular e Integridad Estructural, Coordinador, SNI I Km 12 Carretera Querétaro-Galindo, \\ Mpio. Pedro Escobedo, Sanfandila, Querétaro, Mexico \\ ${ }^{\mathrm{c}}$ Centro de Investigación y de Estudios Avanzados del IPN Unidad Mérida, Investigador Titular 3D, SNI III, Km 6 Ant Carr, a Progreso, 97310 Mérida, Yucatán, \\ Mexico
}

Received 16 October 2017; accepted 25 May 2018

Available online 20 July 2018

\begin{abstract}
In 1935, the Danish company Christiani and Nielsen won the bidding for the design and construction of a viaduct/pier at Port Progreso, Mexico. The design is characterized by the use of stainless steel and massive concrete to the sub and superstructure. The project consisted of a series of arches supported on simple concrete pillars. It consists of three parts: $415 \mathrm{~m}$ access, $1752 \mathrm{~m}$ viaduct, and a $50 \times 205 \mathrm{~m}$ pier. This engineering work is unique in the world for its technological importance by being the first to be designed and built with durability criteria. After being in service for more than 75 years, structural distresses were observed by surface crack appearance at the pile caps and arches, thus external CFRP strips were used as structural reinforcement to avoid collapse of the viaduct. Still, the structural distress continued, thus a new viaduct parallel to the actual was designed and built using durability criteria. This investigation explains the inspection results, CFRP external reinforcement installation, and the design/construction of the new viaduct using durability criteria.
\end{abstract}

(C) 2018 Asociación Española de Ingeniería Estructural (ACHE). Published by Elsevier España, S.L.U. All rights reserved.

Keywords: Durability; Stainless steel; Detailed inspection; Carbon fiber-reinforced polymer; Design

\section{Resumen}

En 1935, la compañía danesa Christiani \& Nielsen ganó el concurso de la obra para el diseño y la construcción de un viaducto/muelle en el puerto de Progreso, México. El diseño se caracterizó por el uso de acero inoxidable y concreto masivo en la sub y superestructura. El proyecto consistió en una serie de arcos apoyados en pilares de concreto simple. Consistió en tres partes: acceso de $415 \mathrm{~m}$, viaducto de $1,725 \mathrm{~m}$ y un muelle de $50 \times 205 \mathrm{~m}$. Esta obra de ingeniería es única en el mundo por sus avances tecnológicos siendo la primera que se sabe fue diseñada con criterios de durabilidad. Después de estar en servicio por más de 75 años, se han observado algunos problemas estructurales como la aparición de grietas en la superficie de algunos arcos y cabezales, es por ello que se planteó la necesidad de reforzar estos elementos con tiras de compuestos de fibra de carbono (CFRP, por sus siglas en inglés) externo, para evitar el colapso de esta estructura. A pesar de este refuerzo, los daños estructurales continuaron, por lo que se recurrió al diseño y construcción de un nuevo viaducto, que estuviera paralelo al primero. Esta investigación explica los resultados de las inspecciones llevadas al cabo, la instalación del refuerzo a base de CFRP y el diseño/construcción del nuevo viaducto en donde se usaron criterios de durabilidad.

(C) 2018 Asociación Española de Ingeniería Estructural (ACHE). Publicado por Elsevier España, S.L.U. Todos los derechos reservados.

Palabras clave: Durabilidad; Acero inoxidable; Inspección en detalle; Carbon fiber-reinforced polymer; Diseño

\footnotetext{
* Corresponding author.

E-mail address: atorres@imt.mx (A.A. Torres-Acosta).
} 


\section{Introduction}

In the last three decades there has been a particular interest in the development of high strength concrete (HSC) materials and more recently in the development of high performance concrete (HPC) structures, which not necessarily implies the use of HSC. Although, in recent years this term has been fashionable, reality indicates that our Mayan, Egyptian, Roman etc., ancestors, understood the importance that the structures have a very long period of service life with no, or low, maintenance actions. In the case of port infrastructure, the enemy to defeat is the corrosion deterioration of the reinforcing (or prestressing) steel. This means that HPC structures in marine environments must tacitly take into account the corrosion factor. In addition to this, there is the economic factor, which requires that a structure has to have a long life performance at a low cost. This is possible in developed countries, but to obtain this in developing countries, it will require a longer timeline.

In the case of Mexico, an example of HPC structure is the Progreso pier, located in the North of the Yucatan Peninsula. This structure was designed and constructed by a Danish contractor named Christiani \& Nielsen after winning the Mexican government design and construction bid for a new pier [2]. As part of the specifications, the Mexican government asked for a design that considered zero corrosion maintenance for 50 years and to be in working condition for at least 100 years. Nowadays it is 82 years since the Progreso Pier construction begun, and 77 years of being in service in good condition and without significant corrosion problems. The old Progreso pier consisted of a $1.7 \mathrm{~km}$ long viaduct and $205 \times 50 \mathrm{~m}$ dock platform. The viaduct is formed by 145 concrete arches supported by 145 pier caps. Those pier caps are supported by two massive concrete circular columns each; hence, there are 290 piles in total. This is what is called a girder: two circular piles joined by a pile cap. The dock platform $(250 \times 50 \mathrm{~m})$ has a similar substructure and structure to the viaduct. It is formed by 250 circular piles, 26 continuous arches and 27 continuous pile caps.

What was the formula to get this long-life structure? Christiani \& Nielsen's design proposal minimized the use of steel to reduce the structure maintenance due to corrosion degradation. The Danish contractor presented a project that took into account, not only the environmental loads of the local atmosphere but also the characteristics of the local construction materials (porous coarse aggregate obtained from crushing locally available limestone).

\section{Old Progresos' viaduct}

\subsection{Construction of old viaduct (1936-1941)}

The structure was conceived of massive concrete and according to reports of the pier's constructors, it was one of first in which type 304 stainless steel smooth rebar was used apparently as shrinkage reinforcement. According to the Danish contractor, this stainless steel rebar was used only to avoid concrete shrinkage in the pile caps due to its massive dimensions. An approximated steel reinforcement index of $0.15 \%$ (equal to the

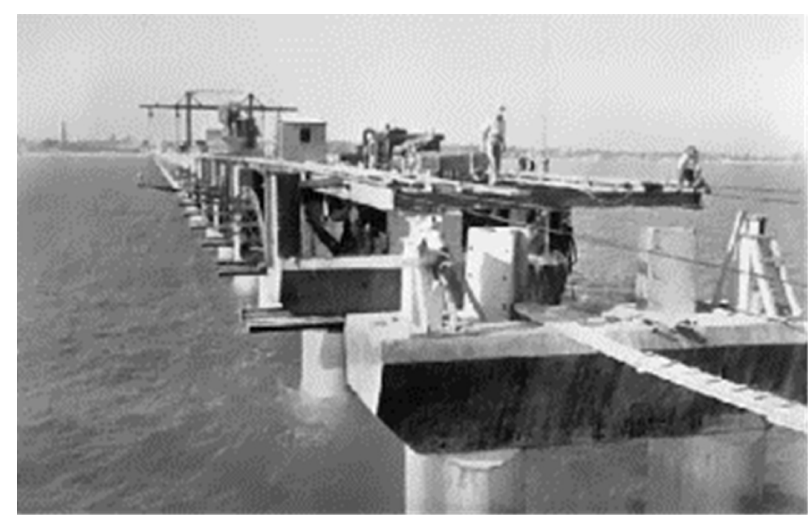

Figure 1. View of cross girders and piles during the construction process.

area of steel divided by the pier cap cross section concrete area) of type 304 stainless steel smooth rebar $(30 \mathrm{~mm}$ in diameter) was used.

The pier consisted of massive concrete and un-reinforced circular piles ( $3 \mathrm{~m}$ in diameter), arches ( $0.40 \mathrm{~m}$ wide) and walls. The pile caps $(2.5 \mathrm{~m}$ in base and $3.0 \mathrm{~m}$ high) were the only structural elements reinforced with stainless steel. In gross numbers, $72,000 \mathrm{~m}^{3}$ of concrete were used: 32 thousand for the circular piles, 30 thousand for the pile caps, arches and walls, and the rest for peripheral supports. A total amount of 23 thousand tons of cement were consumed, from which 17 thousand came from Denmark, and the rest from Mexico and the USA. An approximated total of 220 tons of stainless steel type 304 were used [4], and 170 thousand cubic meters of crushed limestone rock, of which 57 thousand were used as road filler and the rest were used for concrete fabrication. Its structural design was conceived to support a uniformly distributed load of 4 tons $/ \mathrm{m}^{2}$.

According to Christiani \& Nielsen, the allowable design stress applied by the substructure to the foundation was $15 \mathrm{~kg} / \mathrm{cm}^{2}$, which increased to $25 \mathrm{~kg} / \mathrm{cm}^{2}$ when adding the other live loads [2]. Fig. 1 shows the pier construction. This pier is still in service whose maintenance is minimum and it focused on small concrete repairs and painting. Such repairs are associated to the installations of boat docking and boat impacts. Nevertheless, its load rating is in jeopardy at this moment, due to the load increase and traffic frequency, which has caused some structural degradation (i.e. crack appearance in some pile caps and arches).

\subsection{Port extension $(1980 s-1990 s)$}

During the 1980s, the Mexican federal government initiated the construction of a Remote Terminal, to which the old Progreso pier was joined by a 4-lane viaduct. The Progreso pier, whose original viaduct length was $2.2 \mathrm{~km}$, now has an additional $4.5 \mathrm{~km}$. Fig. 2 shows the whole pier extension. This addition transformed the Progreso port to a deep port, which can allow 10-m deep ships to dock.

The project and the materials with which the extension was constructed were very different from the first stage constructed by the Danish contractor. The Progreso deep port has been growing in a regular way during the last decade; to the degree that the traffic on the old $2.2-\mathrm{km}$ viaduct (a 2-lane road) is 


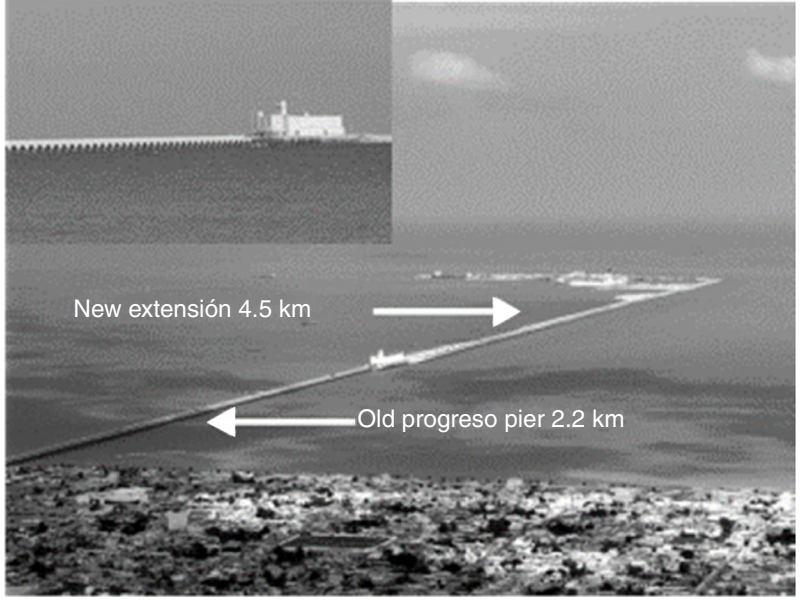

Figure 2. Aerial photograph of the old pier and the extension built in the 80s.

getting very slow, with more frequent vehicular transit and heavier loads. Studies made by the Mexican Institute of the Transportation (IMT in Spanish initials) demonstrated that the loads that the old viaduct is receiving at the moment are already matching the allowed fully factored design loads, which are 10 times greater than those that were supported by the pier structure at the beginning of its operation in 1941 [3].

\subsection{Old viaduct evaluations (2002-2013)}

In 2001, several inspections by the Mexican Institute of Transportation (IMT in Spanish), Research Center and Advanced Studies from IPN (CIN-VESTAV in Spanish), and the College of Engineering from the Autonomous University of Yucatan (FIUADY in Spanish), found evidence of the initiation of electrochemical and structural deterioration [1].

It was obvious that the pier was over demanded, and that a plan was needed to preserve its structural and electrochemical integrity. In common agreement with the Port authorities (the Integral Harbor Administration, API in Spanish), a plan to continuously evaluate the performance of the pier began in 2001. The evaluation program includes at least two annual inspections of its substructure (piles, pile caps and arches). These inspections have and will include load rating capacity of the structure and vehicular dynamic weighing, monitoring the appearance of incipient damages like arch cracking, and monitoring chemical and electrochemical parameters of the materials (i.e. concrete and stainless steel). During these inspections the research group has been able to obtain valuable data so that the harbor authorities can consider a maintenance plan in the short term.

The inspections included concrete material evaluation: petrography analysis, carbonation front, and electrical resistivity; and stainless steel evaluation: metallographic analysis, electrochemical measurements (half-cell potentials and corrosion rate). In addition to material evaluations, the program includes visual and structural surveys of the whole structure, dynamic monitoring (natural frequencies, modes of vibration) and static load evaluation (load vs. strain performance).

Results from the material evaluation performed to the concrete have shown high concentrations of chlorides (on the order of $1-2 \%$ by weight of concrete) at the rebar depth. This amount is about ten to twenty times the amount of chlorides needed to start corrosion of regular carbon steel, and in the barge of initiating corrosion of the stainless steel rebar used in the Progreso pier. Few corrosion problems were observed at the pier cap West and East face although stress corrosion cracking was developed in specific and non-concrete covered rebar hooks. This has warned API that a preventive maintenance program is needed to avoid corrosion problems in the old section of the pier in the near future.

Other results obtained during the continuous evaluation plan, performed by this group, included a detailed crack survey from some of the arches of the viaduct (its pattern is similar to the observed in Fig. 3). This crack intensification has warned API

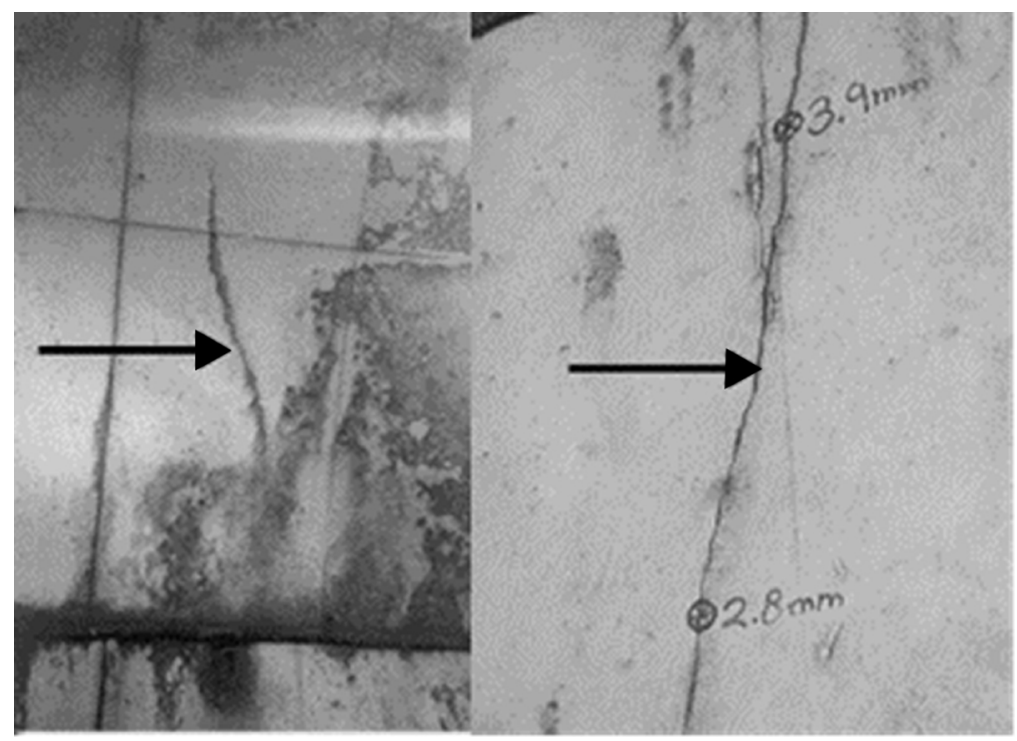

Figure 3. Typical structural cracks observed on the unreinforced concrete arches. 


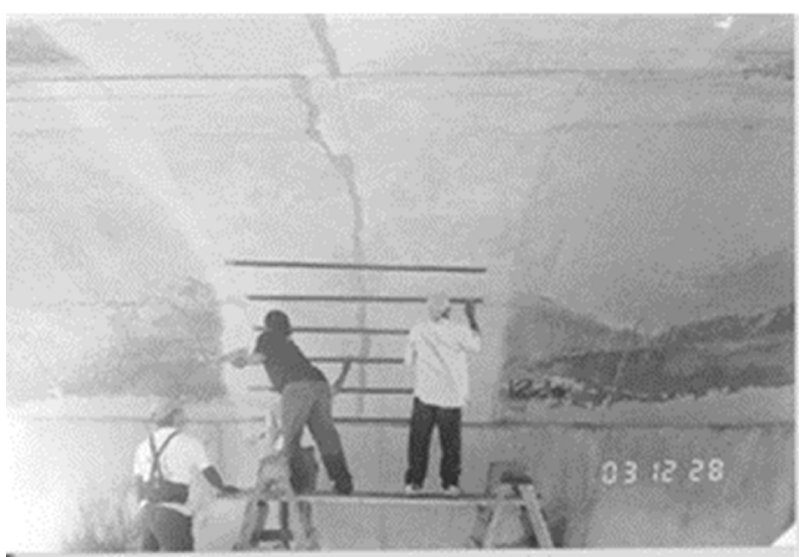

Figure 4. Rehabilitation of one of the cracked arches.

and the working group presented to API a detailed protocol to perform static and dynamic load tests to several of the pier arches [3].

\subsection{Old viaduct rehabilitation (2003-2009)}

As an important consequence of the detection of crack intensification (as it has warned API) and beginning of 2003, 54 arches were externally reinforced with Carbon Fiber-Reinforced Polymer (CFRP) composites, which have shown good corrosion resistance and enough structural strength to hold together the cracked arches (see Fig. 4). The way the CFRP bands were located was conceived to decrease the crack opening due to constant loading of the distress arches.

During a routine inspection in 2007, more arches presents structural cracks, therefore a second rehabilitation work was performed using similar CFRP strips during 2008. However, during this rehabilitation work, additional cracks were observed on the already repaired arches using the localized procedure: CFRP strips glued just in the crack length (Fig. 5). Thus, the procedure of externally reinforced the cracked arches using CFRP strips was changed from localized reinforcement (just placing CFP on top of cracks) to a general reinforcement placing CFP strips on all the width of the arches. In 2009 API obtained additional economical resources to reinforce all the 145 arches of the old viaduct, finishing this work at the end of 2009.

\section{New Progresos' viaduct}

After externally reinforcing all the arches of the new viaduct, the next maintenance strategy to the old viaduct was to avoid the transit of heavy load truck on it. Therefore, the need of a new viaduct construction was unavoidable, because there is no other way to maintain the old viaduct applying the heavy loads without possible collapse of part of this important structure in the port: the only passage to the Progreso's deep port. That is why at the end of 2013 API announced bidding for the executive project of a new viaduct, parallel to the old one, considering durability criteria in the design of this new structure. IMT was again solicited to be the entity to supervise the steps of the executive project, and define the durability criteria during the design of

\section{Detail - A}
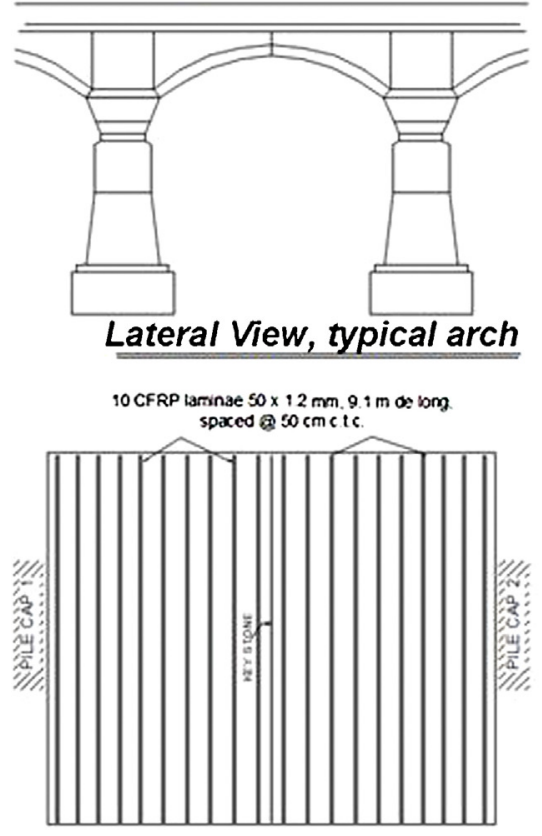

Arch plant view from below

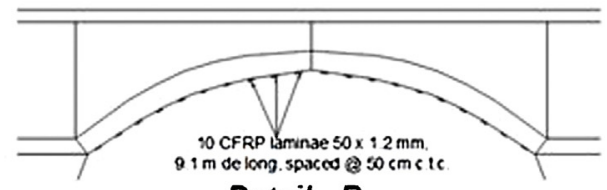

Detail - $B$

\section{Detail - A: Reinforcement}

10 CFRP taminse $50 \times 12 \mathrm{~mm} 9.1 \mathrm{~m}$ Geiong

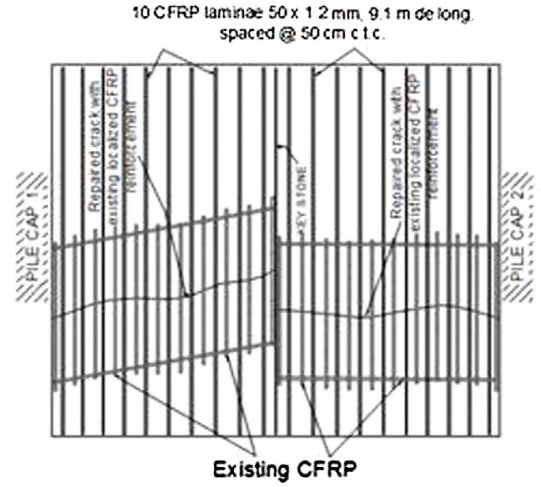

Arch plant view from below with existing localized CFRP reinforcement

Figure 5. CFRP reinforcement of the cracked arches at the entire arch width. (a) Arch without previous reinforcement, (b) arch previously reinforced with localized CFRP strips. 
the materials, construction procedures and future maintenance procedures.

\subsection{Materials specifications}

Although the good durability performance observed in the old viaduct from the use of thick concrete covers $(>20 \mathrm{~cm})$ and stainless steel bars, the possibility of using similar specifications for the new viaduct was rejected due to the price of the stainless steel reinforcement. This material is not available in Mexico, and the need to import all of it was not an option. Therefore, the design group was considering the improvement of the concrete performance, instead of using high cost reinforcement.

The main concern of the design group was to build a new concrete viaduct (bridge) with same service life than the old viaduct, using same porous aggregate (limestone with about 20-25\% total void content). Another concern was to establish some kind of quality control with the cement, since the actual Mexican standard is loose on defining the type, quality, and quantity of the mineral additions integrated to the Mexican cements, to diminish the amount of Clinker on them. Therefore, several specifications were considered to the concrete's mix design to increase the durability of the main material of the new viaduct structure.

Based on the experiences obtained by the design group after more than 15 years of inspection, evaluation, diagnosis, and rehabilitation of several bridges and piers in Mexican marine environment, a concrete's mix design was proposed and some hardened concrete specifications were also defined to achieve a durable concrete with a service life of at least 80 years. The main laboratory tests considered for hardened concrete's quality
Table 1

Concrete mix characteristics.

\begin{tabular}{ll}
\hline Material & Properties \\
\hline Portland cement & $\begin{array}{l}\text { Clinker content }>95 \% ; \text { Blaine }>4000 \mathrm{~g} / \mathrm{cm}^{2} ; \\
\text { cement content }>480 \mathrm{~kg} / \mathrm{m}^{3}\end{array}$ \\
$\begin{array}{l}\text { Water to cement ratio } \\
\text { w/c ratio }\end{array}$ & 0.35 \\
Coarse aggregate & MAS: $19 \mathrm{~mm} ;$ specific gravity $>2.4 ;$ Los \\
& $\begin{array}{l}\text { Angeles wearing machine }<40 \% \\
\text { Fine aggregate }\end{array}$ \\
$\begin{array}{l}\text { Water } \\
\text { Silica fume }\end{array}$ & $\mathrm{Cl}^{-}$content $<90 \mathrm{ppm}$ \\
Electrical wet resistivity & $>5 \%$, but $<10 \%$ \\
Rapid chloride & $>70 \mathrm{k} \Omega \mathrm{cm}$ \\
permeability & $<500 \mathrm{C}$ \\
\hline
\end{tabular}

control was electrical wet resistivity, thus concrete's mix proportion was design to get high values of this physical parameter, which helps to measure indirectly the porosity and the tortuosity. Another specification dealt with the rapid chloride permeability test, which the concrete of this new viaduct need to fulfill. Based on the raw material available in the Yucatan Peninsula to fabricate the concrete (mainly aggregates, water, and Portland cement type), the executive project considered the components listed in Table 1 to obtain a durable concrete for this new viaduct.

\subsection{New viaduct geometry}

The geometry of the structural elements in the substructure as well as the structure in the new viaduct, was also considered
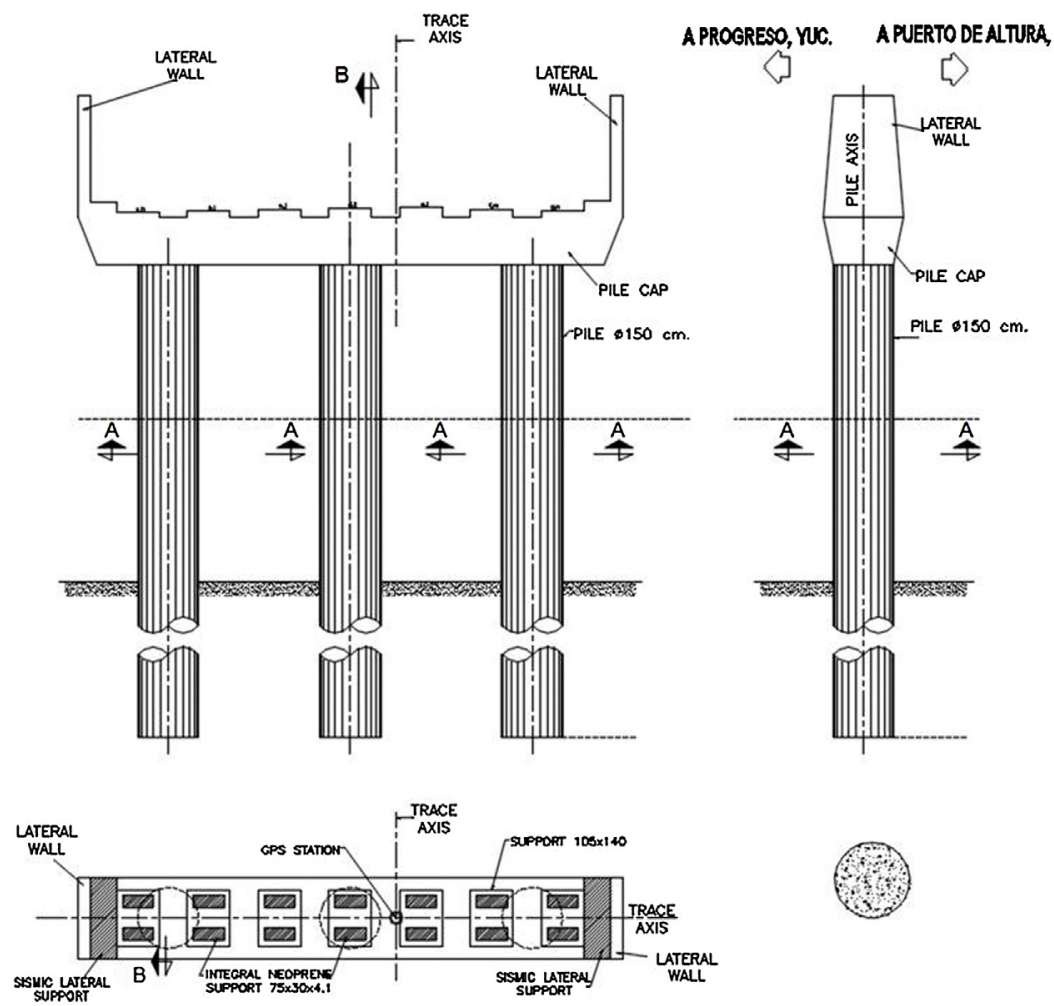

Figure 6. Substructure detail of the Progreso's new viaduct. 

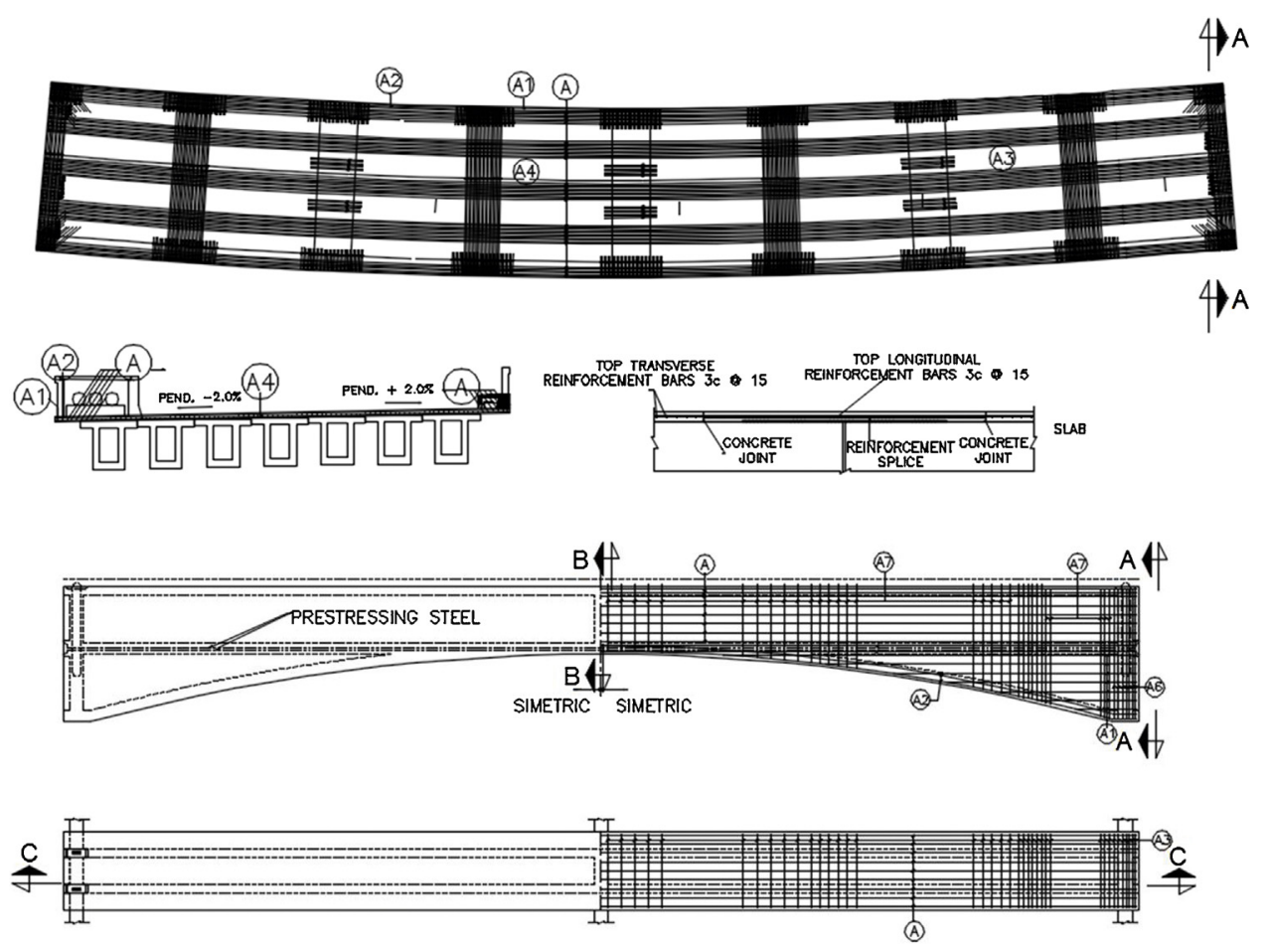

(1)

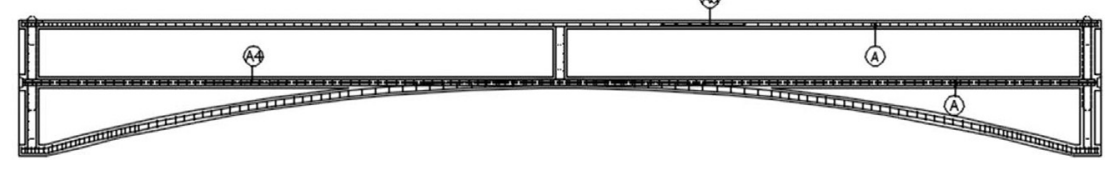

Figure 7. Superstructure details of the Progreso's new viaduct: above deck, below prestressed arched beam.

to get a durable structure with little maintenance (mainly routinely, i.e. bearings, deck surface, deck joints, painting metallic elements, parapets, trenches). The substructure consists of three reinforced concrete pylons $(1.5 \mathrm{~m}$ diameter, $10 \mathrm{~cm}$ concrete cover) and one reinforced pile cap $(1.20 \times 1.50 \mathrm{~m}$, $7 \mathrm{~cm}$ concrete cover), as presented in Figs. 6 and 7.

A second specification considered to increase the durability of the new viaduct was to use in all reinforcement a polymer/ceramic/corrosion inhibitor coating. This coating was considered after a laboratory evaluation before the construction of the new viaduct (no chemical composition of this coating from the manufacturer was obtained). With the experiences observed in substructures in similar tropical marine environment, where epoxy coated rebar was used and failed by corrosion initiation in periods less than 10 years of being in service [5], tests were performed to determine how much is the protection of the steel reinforcement if the concrete was contaminated with chlorides ( $>2 \%$ by cement weight) during the executive project conceptualization. The tested coating included a corrosion inhibitor to increase the chloride critical threshold to initiate corrosion of typical carbon steel.

Finally, a third corrosion protection was defined in the new viaduct executive project, which included a siloxane coating to all concrete elements (no chemical composition of this coating from the manufacturer was obtained): reinforced (substructure/superstructure) and prestressed (superstructure) elements.
Special care was taken to achieve a good penetration of the siloxane coating since the concrete design was to obtain a low permeability material, thus the siloxane molecule redesign to have it smaller than the commercial product has.

\subsection{New viaduct construction}

Construction started in February 2014, and ended in May 2017. Fig. 8 shows some aspects of the construction of Progreso's new viaduct. More details of the construction processes will be published in the near future. The works are programed to end in May next year, but everybody knows that construction works normally ends few weeks later, or even months due to none programed activities or contract extensions.

\section{Conclusions}

Detailed inspection of Progreso's viaduct provided enough quantitative information to determine that the stainless steel bars from the girders are exposed to a high chloride concentration. A structural inspection, including load capacity tests, indicated that the old viaduct is experiencing structural distresses by the formation of surface cracks on arches and pier caps. The rehabilitation techniques used included the use of external CFRP strip reinforcement for the crack opening attenuation. The crack distress continued, thus the design and construction of a new viaduct was 

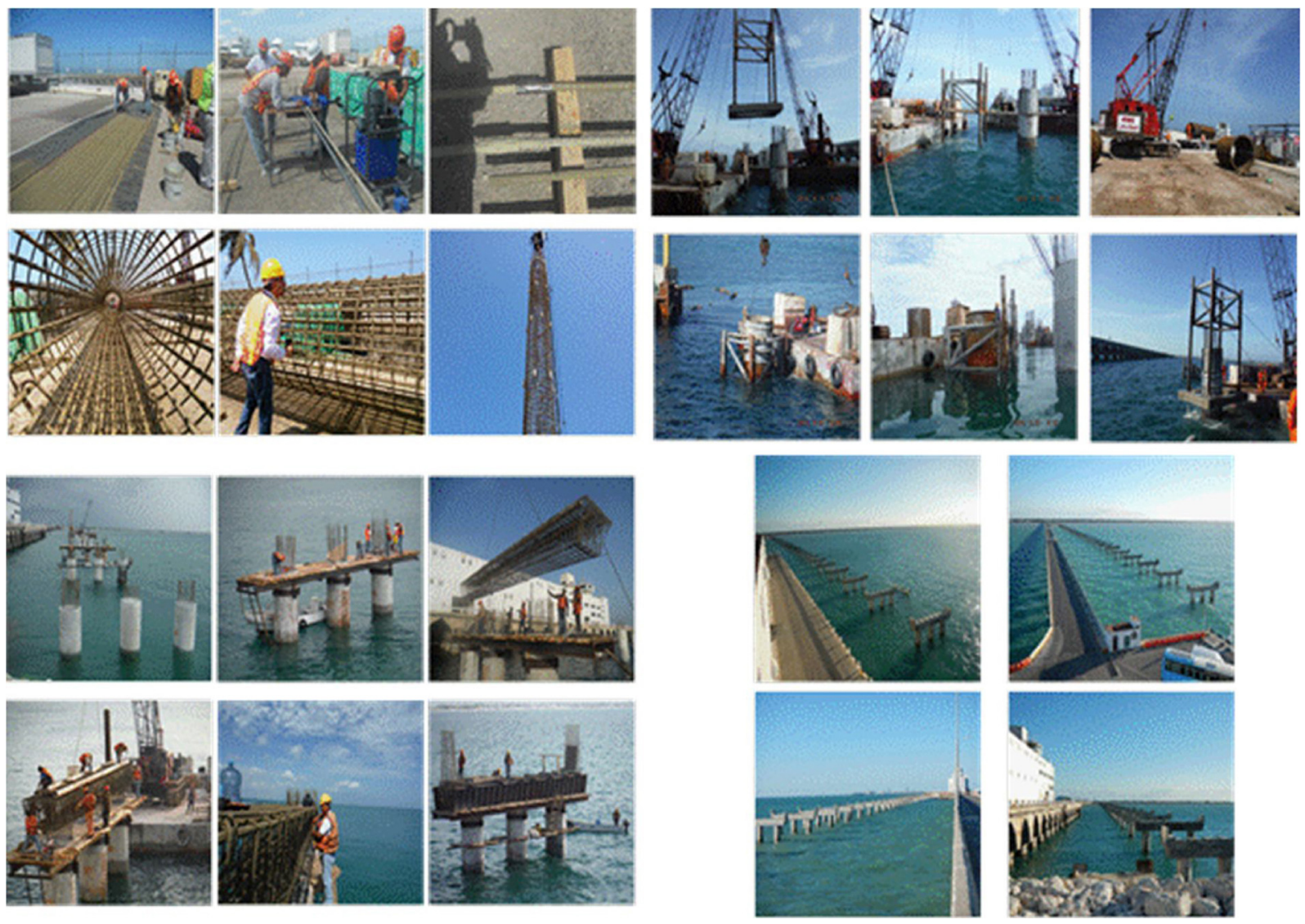

Figure 8. Construction process photographs: substructure construction stage.

proposed to the Port Authorities, thus its construction started in 2014 and ended in 2017. A detailed inspection program has been presented to the Mexican Government authorities to perform a detailed inspection in order to increase the service life of the old viaduct, with strategic, historical and technological importance for the region.

\section{Financial support}

The present investigation was partially supported by the Integral Port Administration (API in Spanish) of Progreso, since the beginning in 2002 until 2017.

\section{Acknowledgements}

The authors are indebted to the Administracion Portuaria Integral (API in Spanish) Progreso for the support of this investigation, design, construction technology development, and innovation. The opinions and findings in this investigation are those of the authors and not necessarily those of the funding agencies.

\section{References}

[1] P. Castro, O. Troconis, E. Moreno, A.A. Torres-Acosta, M. Martínez, A. Nudsen, Inspecting a half-century reinforced concrete pier made with stainless steel reinforcement in Mexico, in: NACE Corrosion/2002 Paper 02207, 2002, pp. 10.

[2] A. Christensen, Pier at Progreso. In 50 Years of Civil Engineering: Christiani \& Nielsen, Copenhagen, Denmark, 1954.

[3] M.J. Fabela-Gallegos, A.A. Torres-Acota, Structural integrity of arches 5 and 12 of the Progreso pier old viaduct. Technical Report 001/2004 Project EE03/04, Instituto Mexicano del Transporte, Sanfandila, Queretaro, Mexico, 2004 (in Spanish).

[4] A. Knudsen, T. Skovsgaard, Ahead of its peers, Concr. Eng. Int. (1999) $58-61$.

[5] A.A. Sagúés, Corrosion Evaluation of Bridges with Epoxy-Coated Rebar. Final Report Contract No. BD544-23 Florida Department of Transpoortation, Tallahassee, FL, USA, 2009. 